\section{Zorana Kostić ${ }^{1}$}

Universuty of Niš, Faculty of Economics
ORIGINAL SCIENTIFIC ARTICLE doi:10.5937/ekonomika1801013K

Received December, 05, 2017

Accepted: February, 19, 2018

\title{
INNOVATIONS AND DIGITAL TRANSFORMATION AS A COMPETITION CATALYST ${ }^{2}$
}

\begin{abstract}
The basic aim of the paper is to examine the relationship between innovation and digital transformation, on the one hand, and the conditions of competition on the other hand. The intensive application of advanced technologies leads to a digital transition and companies which operate in a changing environment must pass through it. The market share depends on, among other factors, the speed of digital transformation. One of the implications of this process is the strengthening of competitive pressure among companies. The correlation between exposure to digitalisation and productivity causes the effects that are reflected an increasing gap between the most successful companies and those less successful who are struggling to survive in the market. The question arises what is the role of innovations in modern business conditions and whether they represent substitution for price competition. The results show that efficient enterprises in the static neoclassical sense can not withstand the pressure of their competitors without innovations. Therefore, it can be noted that innovations are crucial for survival of companies in the capitalist economy.
\end{abstract}

Key words: innovations, digital transformation, competition

JEL classification: D40, 030

\section{ИНОВАЦИЈЕ И ДИГИТАЛНА ТРАНФОРМАЦИЈА КАО КАТАЛИЗАТОР КОНКУРЕНЦИЈЕ}

\begin{abstract}
Апстракт
Основни ициь рада је да сагледа везу између иноваичја и дигиталне трансформащије, с једне стране, и услова конкуреничје, с друге стране. Интензивна примена напредних технологија доводи до дигиталне транзиије кроз коју морају проћи предузећа циома послују у променьивим условима. Висина тржсишног учешћа зависи, између осталог, и од брзине дигиталне трансформаиије предузећа. Једна од импликачија овен прочеса је јачане конкурентског притиска међу предузећима. Веза између изложености предузећа дигитализацији и юихове продуктивности проузрокује ефекте који се огледају у повеціавају јаза између најуспешнијих предузећа и оних мање успешних који се боре за опстанак на тржишту. Поставља се питање какву улогу имају иноваџије у савременим

\footnotetext{
${ }^{1}$ zoksinis@gmail.com

${ }^{2}$ The paper is part of the Project No. 179066 funded by the Ministry of Education, Science, and Technological Development of the Republic of Serbia.
} 
условима пословања предузећа и да ли оне представљу супституцију ијеновној конкуренцији. Резултати до којих се дошло током истраживања показују да и ефикасна предузећа у статичком неокласичном смислу не могу издржати притисак својих конкурената без иновачија. Стога се може констатовати да су иновације кључне за опстанак предузеца у капиталистичкој економији.

Кључне речи: иноващије, дигитална трансформачија, конкуренција

\section{Introduction}

Adequate understanding of the economic essence of competition in the digital environment emphasizes the company's readiness to innovate and monitor technological progress. The fourth industrial revolution, called Industry 4.0, further enhances the role of information and communication technologies in companies. Although, this revolution has a global character, it does not only influence on large companies, but to all actors in the production chain, which is particularly significant for small and medium-sized enterprises. The latest empirical researches show that modern companies compete with innovations and that productivity growth trends are linked to the adoption rate of advanced technologies. The effects of capital investments in advanced technologies are generally positive, but it should not ignore the fact that investments are basically realized by the most productive companies. An analysis on the micro level shows that the link between the exposure of enterprises to digitization and their productivity is propelling the effects that are reflected in increasing the gap between the most successful companies and those less successful ones which are struggling to survive in the market. The subject of research in the paper is to examine the relationship between innovation and digital transformation, on the one hand, and the conditions of competition, on the other hand. The intensive application of advanced technologies leads to a digital transition, which companies operating in a changing environment, must pass through it. The market share, among other factors, depends on the speed of digital transformation of the company. One of the implications of this process is the strengthening of competitive pressure among companies.

Figure 1: Interplay between innovations and digital transformations on the one hand and competition on the other hand

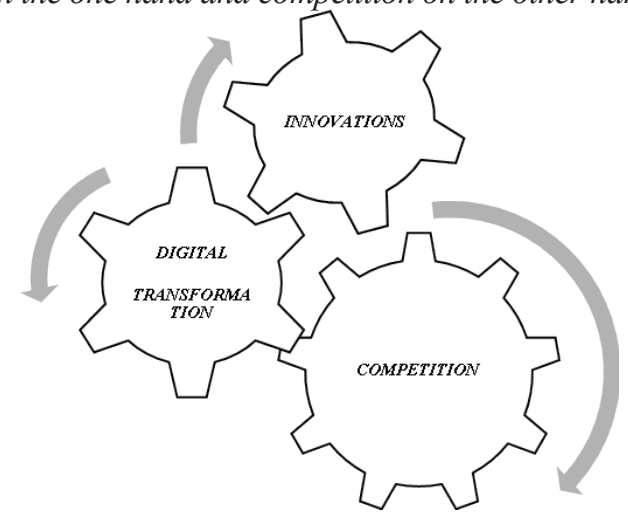

Source: Author 
Adaptation to technological changes in the environment is necessary to compete with competitors. When it comes to digital transformation which have to pass through, it is estimated that the EU's digital market contributes even 375-415 billion euros per year to gross domestic product. Comprehensive use of information-communication tools helps companies to expand their product assortments, to adjust their services, better responding to customer requirements and to reduce inefficiencies in using production factors. On the other hand, the average lifetime of the companies is becoming shorter with a pronounced downward trend. In particular, in 1958, the average lifetime of enterprises in the market was 61 years, in 1980 it was 25 years, and in 2011 it was only 18 years. Digitization has constant pressure on enterprises, so if such trends continue, $75 \%$ of present companies will disappear by 2027. This practically means that digital transition management and moving to digitally driven business models is becoming critical for the survival in the market. (Standard \& Poor's, 2017) McKinsey estimates that the European Union is working at $12 \%$ of its digital potential, with huge differences across sectors and countries, and that there is a positive correlation in all sectors between productivity growth and digital intensity. It is estimated that the European Union could increase gross domestic product by 2.5 billion euros in 2025, if the sectors which lag behind double the digital intensity, and it would additionally result in an annual growth rate of $1 \%$ in the next decade. Otherwise, if the companies missed the digital transition period, there would be increasing territorial and social inequality. (McKinsey \& Company, 2016)

The structure of the paper consists of four parts. After the introduction, the second part of the paper is dedicated to innovations as one of the key factors that influence on competitive market conditions. Then, in the third part of the paper, the correlation between digital transformation and competition between enterprises is shown. The conclusions carried out on the basis of the review of the relevant literature and the guidelines for further researches on this topic are given in the fourth part of the paper.

\section{The role of innovations in creating competitive markets}

Innovations, as a strategic variable that companies take into account when competing in the particular market, get increasing importance. In this part of the paper, competition with innovations is analyzed which is an alternative to price competition in the microeconomic theory. The emphasis on studying prices in the modern market conditions is justified, as long as organizational, strategic and innovative activities are reflected on the products/services price. However, the macro dynamics of capitalism has created the need to incorporate innovation into a neoclassical microeconomic framework. It is undoubtedly that the microeconomic theory of firm behavior contains constraints which are reflected in the unrealistic assumptions (the homogeneity of products, duopoly enterprises have the same size and the same demand curves, the enterprise accurately assumes the price of another enterprise, etc.). However, this does not mean that it is unusable in analyzing real business strategies. Given that competition creates value, and that the microeconomic theory of firm behavior is related to understanding the concept of value, it follows that theory is an integral part of the economic flows analysis. Incorporating innovations into the microeconomic theory of firm behavior provides an understanding the business success of the company through the process of changing the market conditions from perfect to monopolistic competition, from monopolistic competition to the oligopoly and from the oligopoly to a pure monopoly. Baumol notes that innovations are 
the best peripheral part of the standard firm theory. In the neoclassical firm theory, companies compete with the price, but Baumol claims that in the capitalist economy, innovation is the primary competitiveness factor. Less innovative companies will lose their game with their more innovative competitors. Companies may be ineffective in static neoclassical terms, but they can remain profitable if they continue to innovate. Without innovation, even the most efficient company (in a static sense) will not withstand the pressure of its competitors. Therefore, it can be said that innovation is key for survival in the capitalist economy. Baumol claims that innovations are the core of microeconomics, not its periphery, and suggests a model in which innovations are incorporated into a standard (neoclassical) microeconomic framework. This model should lead to an economic theory that is more in line with the real economy. (Baumol, 2002)

The question arises which refers to the role of innovations in modern business conditions and whether they represent substitution for price competition. Contemporary market structures are characterized by competition through innovations that should be complementary rather than competitive to classical price competition. In addition, the competitive advantage gained by innovations is support to the price advantage and the factor for creating competitive market structures. Innovations are successful only if they lead to increased productivity, cost reduction and on that basis provide the same or higher quality for lower price. Since innovations are in the function of achieving price advantage, it should not be understood as an alternative strategy to price competition, but as a complementary activity. (Maksimović, \& Kostić, 2010, p. 39-56)

It is noticeable that innovators are mostly large companies, which are the dominant players on the supply side in the particular market. Large companies can not rely on the unexpected appearance of a new idea, nor leave innovation to coincidence or competitors. The process of creating new or advanced techniques and products is a critical aspect of their everyday business. Such orientation provides continuity in the emergence of innovations and, in the final, survival if the market. Enterprises invest in research and development up to level until the marginal profit becomes zero, i.e. until the marginal revenues and costs of innovation are equalized. Of course, the scope of investment depends on the behavior of other companies. It should be kept in mind that a company which invests less in innovations in the long term, will reduce market share. Researches show that companies which do not invest in innovations in the amount the industry average, will have lower productivity, higher average costs and higher prices for their products. Reducing the risk of increased competition can be achieved by coordinating innovative activities between enterprises through joint ventures, the formation of joint researches, or through various forms of technical cooperation, licenses and patents. In this way, companies reduce the risk of possible competitive overtaking and the cost of improving technology. Companies that do not associate can endanger their market position due to their profits will be less and due to missed chances. Types of horizontal mergers are subject to criticism due to they lead to the creation of noncompetitive markets. However, if research and development is at the core of the merger, the benefits of reducing the risk of introducing new products and technology are greater than the damage caused by market constraints, which implies that such a connection should be approved as it contributes to economic and social progress. (Maksimovic, \& Kostic, 2010, p. 39-56)

Innovations occur in the monopolistic competitive markets where companies are aware of the innovative activities of their rivals and are forced to respond to strong competitive pressures. Since innovations are essential to the survival of a company, they 
can not be left to chance, but innovations must become part of ongoing business activities. Understanding the competition policy in dynamic and evolving markets in the forefront emphasizes innovation, as one of the most important strategic variables which should be taken into account while performing in the particular market. Many of Baumol's ideas that the market mechanism encourages the transformation of inventions into profitable innovations are based on Schumpeter's work. According to Schumpeter, the success of a modern enterprise is unthinkable without innovations, so that his theory of circular flow starting from balance, emphasizes that innovations bring dynamics into a system that is constantly adapting. (Schumpeter, 1939) However, Chemberlin is talking about innovations as part of a static system, and the price that we have to pay to innovate in the static system is too high. Chemberlin insists on the product as a variable and considers sales efforts so that its static framework was not suitable for analyzing product innovations. Chemberlin drew attention to the product as the most volatile component, so that due to innovations, the range of goods is expanded. (Chamberlin, 1953) ${ }^{3}$. As in Baumol's theory of contestable markets, potential competition is the one that induces companies to innovate, which is why their monopoly power is significantly reduced. (Baumol, 1982)

Innovations lead to shift in the demand curve, due to consumers prefer the certain products, but also to shift in the supply curve, due to it will be produced with lower costs. The concept of free-market innovation machine makes the process of innovation as a routine, and companies must follow the dynamics of their competitors when it comes to investing in innovations. Discussion of the way in which the results of innovations are distributed among competing companies through market mechanism is a convincing argument that the sharing innovations in the modern market economy leads to effective results. The capitalist economy is growing, due to oligopolistic industries use innovations as their main competitive weapon, and the routinization of innovation turns it into a reasonably predictable business activity, not into a series of random events. Competition in the market forces companies to continue to innovate and thus grow. However, the question arises, whether the free-market innovation machine will slow down and ultimately cease to generate growth? Research and development are relatively labor-intensive, so that the relative costs of research and development are increasing, companies will allocate less and less amounts, which can lead to slower growth. However, economists believe that the free-market innovation machine will continue to produce economic progress. (Baumol, 2002)

\section{Digital transformation and competition between enterprises}

Enterprises are facing with great challenges that are reflected in more intense competition in the domestic market, and the development of digital technologies changes the business models and consumer expectations. Confronting with the need for the digital transition is present in all markets, so it is often discussed about the digital gap between

${ }^{3}$ See also: Chamberlin, E. H. (1937). Monopolistic or Imperfect Competition? The Quarterls Journal of Economics, 51(4), 557-580. Chamberlin, E. H. (1951). The Impact of Recent Monopoly Theory on the Schumpeterian System. The Review of Economics and Statistics, 33(2), 133-138. Chamberlin, E. H. (1961). The Origin and Early Development of Monopolistic Competition Theory. The Quarterly Journal of Economics, 75(4), 515-543 
companies that are quickly follow rapid technological progress and those that maintain a status quo. On the other hand, we can also talk about the digital gap between consumer expectations and the ability of companies to respond to their requirements. Only those companies that manage to adapt to digital changes in a relatively short period of time, can survive in the market. Strong competitive pressure forces companies to adapt the process of digital transition to business conditions and consumer preferences.

In an environment where information is a basic resource, and entry barriers to a particular market are low, there are changes in business strategies and models. Business changes led by new technologies, change the potential for growth of revenues and profits. There should not be ignored the fact that large companies can be threatened by new, small, innovative companies or startups that entry the market. It can be noted that digital transformation influences on the change of the market structure and competition between enterprises. Competitive pressure between businesses in the digital environment is becoming stronger: when the elasticity of substitution is expressed, when there is a high degree of products/services interchangeability, and while building relationships with consumers by encouraged purchasing habits, providing consumer services and post-sale maintenance services. (Kostić, \& Rađenović, 2017)

Digital transformation has become the central theme of the business strategies and the all size enterprises development. It is a way to achieve bigger business results by using new technologies. In addition, digital transformation is not only the introduction of new technologies and the process of customizing products and services, but also redefining business models, optimizing business processes and managing organizational changes. (Privredna komora Srbije, 2017) Digitization involves using of modern technologies for business in order to transform it into a business model fully oriented to the consumers needs, and model that is currently adapt to market demand. If we look at the structure of the companies around the world, it is noticed that the small and medium-sized enterprises have the majority, so the process of digitization basically affects the most these companies. Current phase of industrial revolution allows that advanced technologies become available to all companies regardless of their size. The distribution of modern business tools is done between micro, small, medium and large enterprises. Digitalized enterprise is the one in which the level of automation of business processes is at the highest level so there is no repetition of jobs, operating costs are minimized and it can be planned and anticipated, business functions are logically connected so that the output is used as input of the other, current insight into the real state is possible, communication with stakeholders (customers, suppliers and others) is automated, the risk for human error is minimized, jobs are performed in a reliable business information system etc. Digitized business enables constant presence in the market and taking advantage of opportunities. The digitization process is often described as an exponential technological advancement that will make consumers more powerful and bring more competition. Through the digitization process, an added value is created, the way from the producer to the buyer is reduced, and the price of the product is decreased. (Cominng Computer Engineering, 2017) In the digital economy only those companies that react to change instinctively and turn them into a strategic advantage will survive. Companies which adapted elemental to changes will miss out opportunities.

Empirical research shows that companies have high expectations from digitization, which are reflected in increasing annual revenues and reducing costs by 5 to 10 percent over a period of three to five years. However, in order to achieve significant results, investments in digital ventures are needed, which only a small number of companies can provide. The 
introduction of digitization in enterprises is not only crucial in the fight against competitors, but also for the survival in the market. Adequately adjusting to the digital age and taking advantage of its benefits, highlights six elements that build a high performance digital enterprise, which are: 1) strategy and innovation; 2) decision making of customers; 3) automation of processes; 4) organization; 5) technology; 6) data and analytics. Every type of digitization does not need develop and application all six elements to the same extent. These framework provides an adequate structure for managing big data digital programs. (McKinsey \& Company, 2017)

Key changes which digital transformation brings refer to:

a) Consumer experience: Traditional marketing techniques are dramatically expanded to better understand consumer behavior and needs: customer segmentation using advanced tools and information available on the Internet, familiarity with consumer behavior, tastes, needs through social networks, development of predictive marketing, fully customized applications, and digital self-service.

b) Business Processes: Performance improvement, employee networking and job mobility, decision-making based on advanced analytics and data. Consumers and employees communicate more with algorithms, not with other employees in the company.

c) Business models: There is the transformation from the physical into the digital, increasing number of fully digitalized products and services, to a complete transformation of the organizational model and the redefinition of the business boundaries. (Coming Computer Engineering, 2017)

The correlation between investments in information-communication tools and productivity growth in production can be seen more accurately at the micro level. Leading companies are investing heavily in digital transformation in order to increase productivity. But there are those companies that lag behind with productivity growth due to insufficient investments. Over time, these companies will have to increase investments in digital transformation if they want to catch up market leader and to respond to strong competitive pressure, otherwise they will be forced to exit the market. In the meantime, the performance of the industry will also reflect on the performance of the leader and satellites. Empirical research conducted on a representative sample of 644 production companies with more than 10 employees in five major European regions: Lombardy (Italy), Baden-Württemberg and Bavaria (Germany), Catalonia (Spain) and Rhône-Alpes (France) analyzed whether and to what extent enterprises are using advanced technologies (e.g. ERP, CRM, virtual marketplace, etc.) and how it reflects on productivity growth. The analysis showed that most companies in the sample $(55.9 \%)$ adopted at least one IT instrument, which is a result that indicates that the digital transition is still far from complete. Observed by size of enterprises, it is not surprising that there is a positive link between the size of the enterprises and the degree of digitization. Namely, the percentage of enterprises which deal with digitization, which do research and development and which are internationally active, grow with their size, and in such enterprises, the participation of the family in the management is small. (Veugelers, 2017) In addition, productivity of the company is growing in line with the number of applied information and communication tools, it is noticeable that there is an increasing productivity by every new information communication tool. If we look at the effects on productivity when introducing digital tools by market leaders, we will see that the adoption of a single information and communication instrument generates $3 \%$ of productivity growth compared to digitally inactive companies, and the use of additional tools further increases productivity. 
This is in line with the conclusion that the process of technological diffusion is uneven and that companies adopt new technologies only when leading companies adapt to the business environment in the country. (Van Ark, 2005; Andrews et al, 2015)

A positive relationship between digitization and productivity can also be shown by a regression model that quantitatively treats this relationship. One of the regressive models regards labor productivity as a function of investing in research and development, internationalization and ownership structures in the enterprise. If digitization is treated in terms of adopting at least one information-communication tool, it can be concluded that there is a positive link between digitization and the level of productivity in the company. When advanced tools are applied by $20 \%$ of the most productive enterprises, this leads to higher productivity growth (over 18\%), but also to greater gap between leaders and satellites. (Altomonte, Aquilante \& Ottaviano, 2012)

In order to monitor the development of digital performance, the composite Digital Economy and Society Index (DESI) has been created to combine relevant indicators such as: 1) connectivity (fixed internet access, mobile internet access, internet speed and accessibility); 2) human capital (basic skills and use, advanced skills and development); 3) using internet (content, communication and online transactions); 4) integration of digital technologies (digitalization of business processes and e-commerce); and 5) digital and public services (e-government). (European Commission, 2017) When we talk about digital and public administration, data obtained during the research show that companies in Serbia are increasingly using electronic public services for performing administrative tasks such as obtaining information, downloading and returning forms.

Figure 2: Using of electronic public administration services in companies in the Republic of Serbia (in \%)

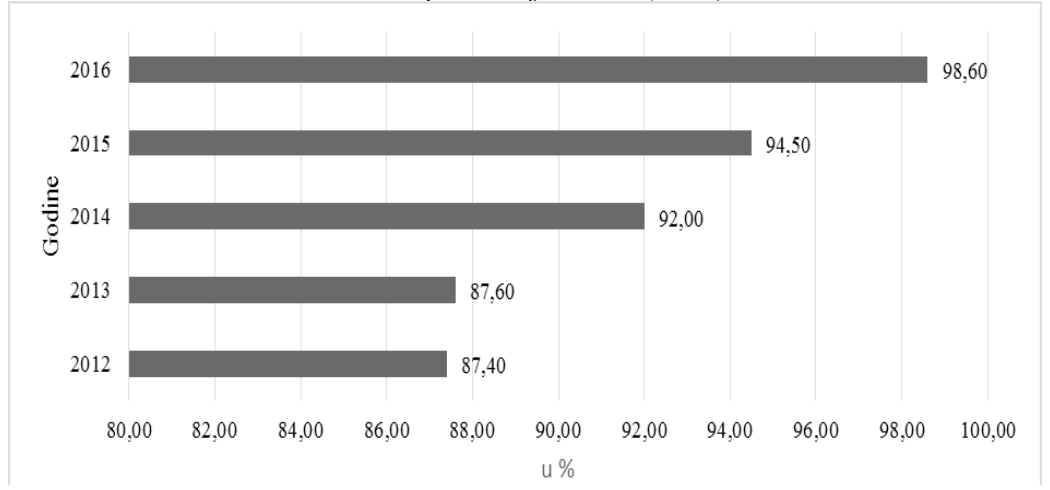

Source: RATEL, Pregled tržišta telekomunikacija i poštanskih usluga u Republici Srbiji u 2016. godini. str. 102.

Based on the data from the Statistical Office of the Republic of Serbia presented in the Figure 2, it can be seen that $98.6 \%$ of enterprises used these services in 2016. Accelerated expansion of e-government service in Serbia has caused such a high percentage of companies using these services. Over $80 \%$ of the total number of companies in Serbia with an internet connection have their own website, more than one third of the company has used one of the social networks, and about $9 \%$ of companies use cloud services for storing data. Comparative 
analysis with European Commission data for 2017, shows that two thirds of companies use social networks, while 13\% of companies in European union use cloud services.

In order to measure and monitor the digital gap among countries, International Telecommunication Union publishes indicators of the development in information and communication technologies. Value of the index of development in information and communication technologies in Serbia in the period from 2012 to 2016 is: $5.62 ; 6.03 ; 6.21$; 6.76; 6.87; respectively. Therefore, it is evident that the information society in Serbia has been developing in the previous period. However, the analysis of the index structure shows that there is a satisfactory level of information and communication skills, but also that there is a disproportion between the available capacities based on the existing infrastructure and the utilization of these capacities through using electronic communications services. (International Telecommunication Union, 2017)

\section{Conclusion}

Companies are facing with the need for the digital transition in all markets. It often spends out a digital gap between companies that are rapidly following technological progress and those that maintain a status quo. Only those companies that manage to adapt to digital changes in a relatively short period of time can survive in the market. The results show that strong competitive pressure forces companies to adapt the process of digital transition to business conditions and consumer preferences. The analysis of the market structures in Serbia and the European Union shows that the business majority consists of small and medium enterprises, and it can be concluded that the process of digitization basically affects these entities. However, it should not ignore large companies that are innovation holders and which dictate the pace of digital transformation.

The paper examines the impact of innovation and digital transformation on the conditions of competition in the market. By reviewing the relevant literature, it has been concluded that the intensive application of advanced technologies leads to the digital transition and the speed of digital transformation significantly influences on the market position of the company. The consequences of this process are: strengthening competitive pressure among companies, but also increasing the gap between the most successful companies and those less successful who are struggling to survive in the market. Innovations are becoming crucial for the survival of companies in the capitalist economy. The effects of innovation and digital transformation on productivity are on average positive, but they are basically led by the most productive companies. Large enterprises, as the bearers of innovation, can not rely on the unexpected appearance of a new idea, nor can leave innovations to competitors or coincidence. Less innovative companies will lose the game with more innovative competitors. Since innovations are in the function of achieving price advantage, it should not be understood as an alternative strategy to price competition, but as a complementary activity. A discussion about the way in which the results of innovations are distributed among companies through market mechanism is a convincing argument that the sharing innovations in a modern market economy leads to effective economic results. All this things considered, it can be concluded that there is a two-way connection between innovations and competition: while on the one hand innovations encourage competition between enterprises, on the other hand, competitive pressure is the primary factor that forces companies to continue innovating. 


\section{Reference}

Altomonte, C., Aquilante, T., \& Ottaviano, G. I. (2012). The triggers of competitiveness: the EFIGE cross-country report. Belgium: Blueprint 17, Bruegel.

Andrews, D., Criscuolo, C., \& Gal, P. (2015). Frontier Firms, Technology Diffusion and Public Policy: Micro Evidence from OECD Countries. OECD Productivity Working Papers 2, OECD Publishing.

Baumol, W. J. (1982). Contestable Markets: An Uprising in the Theory of Industry Structure. The American Economic Review, 72(1), 1-15.

Baumol, W. J. (2002). The free-market innovation machine: Analyzing the growth miracle of capitalism. Princeton university press.

Chamberlin, E. H. (1937). Monopolistic or Imperfect Competition? The Quarterly Journal of Economics, 51(4), 557-580.

Chamberlin, E. H. (1951). The Impact of Recent Monopoly Theory on the Schumpeterian System. The Review of Economics and Statistics, 33(2), 133-138.

Chamberlin, E. H. (1953). The Product as an Economic Variable. The Quarterly Journal of Economics, 67(1), 1-29.

Chamberlin, E. H.(1961). The Origin and Early Development of Monopolistic Competition Theory. The Quarterly Journal of Economics, 75(4), 515-543.

Coming Computer Engineering. Retrived October 5, 2017, from http://coming.rs/ business_it_magazin/digitalna_transformacija_poslovanja

European Commission, Digital Singal Market. Retrived October 5, 2017, from https:// ec.europa.eu/digital-single-market/en/desi

International Telecommunication Union. Retrived October 5, 2017, from http://www.itu. int/en/Pages/default.aspx

Kostić, Z., \& Rađenović, Ž. (2017). Analiza konkurencije zdravstvenih informacionih sistema primenom softvera za višekriterijumsko odlučivanje. Info M, 16(62), 44-50.

Maksimović, L., \& Kostić, M. (2010). Modeli cenovne konkurencije na oligopolskom tržištu i njihova primenljivost. Ekonomski horizonti, 12(2), 39-56.

McKinsey \& Company (2016). Digital Europe: Pushing the Frontier, Capturing the Benefits. McKinsey Global Institute.

McKinsey \& Company. Retrived October 5, 2017, from https:/www.mckinsey.com/ business-functions/organization/our-insights/six-building-blocks-for-creating-ahigh-performing-digital-enterprise

Privredna komora Srbije. Retrived October 5, 2017, from http://www.pks.rs/Sresult.asp $\mathrm{x} ? \mathrm{cx}=009205315265557346388 \% 3 \mathrm{~A} 8 \mathrm{jb} \_$akz-mo8\&cof=FORID\%3A11\&q=digital izacija\&ie $=$ utf-8

RATEL (2017). Pregled tržišta telekomunikacija i poštanskih usluga u Republici Srbiji u 2016. godini.

Republički zavod za statistiku. Retrived October 4, 2017, from http://www.stat.gov.rs/ WebSite/Default.aspx 
Schumpeter, J. A. (1939). Business Cycles - A Theoretical, Historical and Statistical Analysis of the Capitalist Process (with an introduction, by Rendigs Fels izd.). New York: McGraw-Hill Book Company.

Standard \& Poor's. Retrived October 5, 2017, from https:/www.standardandpoors.com/ en_US/web/guest/ratings/ratings-criteria

Stojanović, B., \& Vučić, V. (2008). Competition policy and economic efficiency. Ekonomika, 54(3-4), 33-40.

Van Ark, B. (2005). Towards an Integrated System of Growth, Productivity and National Accounts for the European Union. OECD Workshop on Productivity Measurement.

Veugelers, R. (2017). Remaking Europe: the new manufacturing as an engine for growth. Belgium: Blueprints. 